\title{
Regulation of vitamin D-1a-hydroxylase and -24-hydroxylase expression by dexamethasone in mouse kidney
}

\author{
N Akeno, A Matsunuma, T Maeda, T Kawane and N Horiuchi \\ Department of Biochemistry, Ohu University School of Dentistry, Koriyama 963-8611, Japan \\ (Requests for offprints should be addressed to N Horiuchi; E-mail: fwga4746@mb.infoweb.ne.jp)
}

\begin{abstract}
We investigated the effects of dexamethasone on vitamin D-1 $\alpha$-hydroxylase and -24-hydroxylase expression and on vitamin D receptor (VDR) content in the kidneys of mice fed either a normal (NCD) diet or a calcium- and vitamin D-deficient (LCD) diet for 2 weeks. For the last 5 days mice received either vehicle or dexamethasone ( $2 \mathrm{mg} / \mathrm{kg}$ per day s.c.). Dexamethasone significantly increased plasma calcium concentrations without changing plasma concentrations of 1,25-dihydroxyvitamin $\mathrm{D}_{3}$ $\left(1,25(\mathrm{OH})_{2} \mathrm{D}_{3}\right)$ in both NCD and LCD groups. Northern blot and enzyme activity analyses in NCD mice revealed that dexamethasone increased renal VDR mRNA expression modestly and greatly increased 24hydroxylase mRNA abundance and enzyme activity, but did not affect 1 $\alpha$-hydroxylase mRNA abundance and enzyme activity. In mice fed an LCD diet, dexamethasone increased renal VDR mRNA expression 1.5-fold, decreased $1 \alpha$-hydroxylase mRNA abundance (52\%) and
\end{abstract}

activity (34\%), and markedly increased 24-hydroxylase mRNA abundance (16-fold) and enzyme activity (9-fold). Dexamethasone treatment did not alter functional VDR number $\left(\mathrm{B}_{\max } 125-141 \mathrm{fmol} / \mathrm{mg}\right.$ protein) or ligand affinity $\left(K_{\mathrm{d}} 0 \cdot 13-0 \cdot 10 \mathrm{nM}\right)$ in LCD mice. Subcutaneous injections of $1,25(\mathrm{OH})_{2} \mathrm{D}_{3}(0 \cdot 24 \mathrm{nmol} / \mathrm{kg}$ per day for 5 days) into NCD mice strongly increased renal 24hydroxylase mRNA abundance and enzyme activity, while there was no effect of dexamethasone on renal 24-hydroxylase expression in these mice. This may be due to overwhelming induction of 24-hydroxylase by $1,25(\mathrm{OH})_{2} \mathrm{D}_{3}$. These findings suggest that glucocorticoidinduced osteoporosis is caused by direct action of the steroids on bone, and the regulatory effect of glucocorticoids on renal 25-hydroxyvitamin $\mathrm{D}_{3}$ metabolism may be less implicated in the initiation and progression of the disease.

Journal of Endocrinology (2000) 164, 339-348

\section{Introduction}

The 1932 description of glucocorticoid excess by Harvey Cushing suggested symptomatic osteoporosis as a clinical feature (Cushing 1932). Increased concentrations of glucocorticoids are thought to alter bone remodeling by decreasing bone formation and increasing bone resorption, resulting in a net loss of bone volume in humans and animals (Lukert \& Raisz 1990, Reid 1997). Furthermore, glucocorticoids decrease net intestinal calcium absorption (Klein et al. 1977, Aloia et al. 1984), although details of the mechanism are still unclear. Glucocorticoids have been shown to increase renal calcium excretion (Suzuki et al. 1983, Reid \& Ibbertson 1987, Cosman et al. 1994). Therefore, the net effect of glucocorticoid in intestine and kidney results in a negative calcium balance which leads to secondary hyperparathyroidism, as evidenced by increased immunoreactive parathyroid hormone (PTH) in steroidtreated patients (Suzuki et al. 1983). Glucocorticoids elicit phosphaturia and decrease the tubular reabsorption of phosphate (Cosman et al. 1994). A dexamethasone- induced decrease in the maximum velocity $\left(\mathrm{V}_{\max }\right)$ of phosphate transport across the renal brush border membrane correlates with reductions in renal mRNA coding for the sodium gradient-dependent phosphate transporter and in renal content of the protein (Levi et al. 1995). Thus, glucocorticoids have direct effects on the kidney, although overall renal effects include results of secondary hyperparathyroidism.

Metabolism of 25-hydroxyvitamin $\mathrm{D}_{3}\left(25 \mathrm{OHD}_{3}\right)$, a circulating form of vitamin $\mathrm{D}_{3}$, occurs mainly in the kidney where it is converted into 1,25-dihydroxyvitamin $\mathrm{D}_{3}\left(1,25(\mathrm{OH})_{2} \mathrm{D}_{3}\right)$, the active form of the vitamin, and 24,25 -dihydroxyvitamin $\mathrm{D}_{3}\left(24,25(\mathrm{OH})_{2} \mathrm{D}_{3}\right)$, a catabolic product and putative regulator of bone formation (DeLuca 1988, Ono et al. 1996, Haussler et al. 1998). The synthesis of these substances is reciprocally regulated by a number of factors including $1,25(\mathrm{OH})_{2} \mathrm{D}_{3}$ and PTH (DeLuca 1988, Haussler et al. 1998). The vitamin D-endocrine system is the major regulator of mineral ion metabolism, while glucocorticoids also affect such metabolism, so suspicion has arisen that glucocorticoids can influence $25 \mathrm{OHD}_{3}$ 
metabolism in the kidney. However, studies attempting to demonstrate such an effect have yielded conflicting results. Chronic glucocorticoid excess has had varied reported effects on plasma $1,25(\mathrm{OH})_{2} \mathrm{D}_{3}$ concentrations, including increases (Bikle et al. 1993, Cosman et al. 1994), no change (Seeman et al. 1980, Prummel et al. 1991), and decreases (Chesney et al. 1978, Morris et al. 1990). Moreover, whether chronic glucocorticoid excess influences plasma concentrations of $24,25(\mathrm{OH})_{2} \mathrm{D}_{3}$ is not known. Clearance rates of $1,25(\mathrm{OH})_{2} \mathrm{D}_{3}$ have been found to be normal in humans receiving glucocorticoids (Seeman et al. 1980), although the steroids accelerate degradation of $1,25(\mathrm{OH})_{2} \mathrm{D}_{3}$ in intestinal mucosa (Carré et al. 1974). Intestinal receptors for $1,25(\mathrm{OH})_{2} \mathrm{D}_{3}$ have been reported to be increased in rats (Hirst \& Feldman 1982a) by glucocorticoids, but decreased in mice (Hirst \& Feldman 1982b). These conflicting results involving the complexes of vitamin $\mathrm{D}$ metabolism accentuate the importance of defining regulatory effects of glucocorticoids on the expression of 1 $\alpha$ - and 24-hydoxylases in the kidney.

Genes encoding vitamin D-1 $\alpha$-hydroxylase, an enzyme responsible for $1,25(\mathrm{OH})_{2} \mathrm{D}_{3}$ synthesis, and 24hydroxylase, an enzyme responsible for production of $24,25(\mathrm{OH})_{2} \mathrm{D}_{3}$ and $1 \alpha, 24,25$-trihydroxyvitamin $\mathrm{D}_{3}(1 \alpha$, $24,25(\mathrm{OH})_{3} \mathrm{D}_{3}$, have recently been cloned, permitting the hydroxylase mRNAs to be quantified in mice (Akeno et al. 1997, Takeyama et al. 1997). The present study was designed to determine whether dexamethasone affects renal $1 \alpha$ - and 24-hydroxylase gene expression and activity in mice. We found that dexamethasone modestly decreases renal $1 \alpha$-hydroxylase expression in mice fed a low calcium and vitamin D-deficient (LCD) diet, while clearly increasing 24-hydroxylase gene expression and activity in the kidneys of mice fed either normal (NCD) or LCD diets.

\section{Materials and Methods}

\section{Diets and animals}

Male ddY mice (8 weeks old) were purchased from SLC (Hamamatsu, Japan). They were fed either a normal diet (rodent chow containing $1.6 \mathrm{IU}$ vitamin $\mathrm{D}_{3} / \mathrm{g}$ chow, $1.42 \%$ calcium and $1.16 \%$ phosphorus) or a low calcium and vitamin D-deficient diet containing $0 \cdot 01 \%$ calcium and $0.3 \%$ phosphorus (AIN-93 G minus calcium and vitamin D) for 2 weeks (Reeves et al. 1993a,b). Both diets were obtained from Oriental Bio-service Co. (Tokyo, Japan). The mice receiving a normal diet were designated the NCD group and animals fed a synthetic diet (AIN-93 $G$ minus calcium and vitamin D) were designated the LCD group. Animals received daily injection (s.c.) of either vehicle alone (isotonic saline) or dexamethasone phosphate (Sigma Chemical Co., St Louis, MO, USA) at a dose of $2 \mathrm{mg} / \mathrm{kg}$ for 5 days. They were killed by cervical dislocation under anesthesia $24 \mathrm{~h}$ after the last administration of dexamethasone. Total plasma calcium and phosphorus levels were measured colorimetrically. Plasma $1,25(\mathrm{OH})_{2} \mathrm{D}_{3}$ was measured by a radioreceptor assay with calf thymus receptor and $\mathrm{C} 18 / \mathrm{OH}$ cartridge purification using a $1,25(\mathrm{OH})_{2} \mathrm{D}_{3}$ kit (a gift from Yamasa Shoyu Co., Choshi, Japan) (Saikatsu et al. 1993). Plasma mouse PTH was determined using the rat PTH IRMA kit (Immunotopics, Inc., San Clemente, CA, USA) (Meyer et al. 1994). Kidneys were removed and either homogenized for determination of $1 \alpha$-hydroxylase and 24-hydroxylase activities, or rapidly frozen in liquid $\mathrm{N}_{2}$ for isolation of total RNA. The animal studies were approved by the Animal Care and Use Committee of Ohu University and conducted in accordance with the Guidelines for the Care and Use of Laboratory Animals.

\section{Probes for $m R N A$ determination}

The probe used in this study for 24-hydroxylase was a previously cloned $3 \cdot 3 \mathrm{~kb}$ full-length cDNA (Akeno et al. 1997). That for $1 \alpha$-hydroxylase was $2 \cdot 4 \mathrm{~kb}$ full-length cDNA which we have cloned, and the sequence was identical to that reported by Takeyama et al. (1997). The mouse vitamin D receptor (VDR) probe was a $562 \mathrm{bp}$ cDNA synthesized by RT-PCR and cloned into the pT7Blue T-vector (Invitrogen, San Diego, CA, USA). The nucleotide sequence of the VDR cDNA corresponded to nucleotide numbers 486-1047 in the report of Kamei et al. (1995). Probes were labeled with $\left[\alpha-{ }^{32} \mathrm{P}\right] \mathrm{dCTP}(110 \mathrm{TBq} / \mathrm{mmol}$; ICN Biochemicals, Costa Mesa, CA, USA) by the random oligopriming method using a Megaprime DNA labeling kit (Pharmacia Biotech UK Ltd., Bucks, UK). The cyclophilin cDNA probe was used to control loading of RNA on the gels and transfer onto membranes.

\section{Northern blot analysis}

Total RNA was extracted from kidney cortex using guanidine thiocyanate as described previously (Akeno et al. 1997). Total RNA was fractionated in $1 \cdot 2 \%$ agarose gels containing formaldehyde and transferred onto Hybond$\mathrm{N}^{+}$membranes (Amersham International plc). The membranes were hybridized with mouse $1 \alpha$-hydroxylase, 24-hydroxylase, VDR or cyclophilin cDNA probes that had been labeled with $\left[\alpha-{ }^{32} \mathrm{P}\right] \mathrm{dCTP}$ by the Megaprime DNA labeling system. Hybridization was performed for 2 days at $42{ }^{\circ} \mathrm{C}$ in $50 \%$ formamide, $5 \times$ Denhardt's solution, $0.5 \%$ SDS, and $5 \times \operatorname{SSPE}(150 \mathrm{mM} \mathrm{NaCl}, 10 \mathrm{mM}$ sodium phosphate, and $1 \mathrm{mM}$ EDTA), after which the membranes were washed in $0 \cdot 1 \times \mathrm{SSPE}-0 \cdot 1 \%$ SDS at $65{ }^{\circ} \mathrm{C}$ for $15 \mathrm{~min}$ and exposed to Hyperfilm at $-80{ }^{\circ} \mathrm{C}$ with intensifying screens. The amounts of mRNA were quantified by densitometric scanning of the autoradiograms, and the abundance of mRNAs of interest was normalized relative to cyclophilin mRNA. 


\section{Measurement of renal hydroxylase activities}

The kidney cortex was minced, then washed in ice-cold homogenization buffer (0.19 $\mathrm{M}$ sucrose, $25 \mathrm{mM}$ sodium succinate, $2 \mathrm{mM} \mathrm{MgCl}$, $1 \mathrm{mM}$ EDTA, $20 \mathrm{mM}$ TrisHepes, $\mathrm{pH} 7 \cdot 4$ ), and homogenized in the same solution $(20 \mathrm{ml} / \mathrm{g}$ tissue $)$. For measurement of $1 \alpha$-hydroxylase activity, $4 \mu \mathrm{g} 25 \mathrm{OHD}_{3}$ (Phillips Duphar, Amsterdam, The Netherlands), dissolved in $10 \mu \mathrm{l}$ ethanol, was added to $1 \mathrm{ml} \mathrm{5 \%} \mathrm{homogenate,} \mathrm{and} \mathrm{the} \mathrm{mixture} \mathrm{was} \mathrm{incubated} \mathrm{at}$ $37{ }^{\circ} \mathrm{C}$ for $30 \mathrm{~min}$. The reactions were stopped by the addition of $1 \mathrm{ml}$ acetonitrile. $1,25(\mathrm{OH})_{2} \mathrm{D}_{3}$ synthesis was quantified using a $1,25(\mathrm{OH})_{2} \mathrm{D}_{3}$ kit from Yamasa Shyoyu Co. Data are expressed as $\mathrm{fmol} / \mathrm{mg}$ protein per min. Because $1 \alpha$-hydroxylase activity was very low, we used the sensitive method of Lobaugh \& Drezner (1983) who showed that in vitro production of $1,25(\mathrm{OH})_{2} \mathrm{D}_{3}$ by mouse kidney homogenates can be measured accurately and at low concentration. This method indicated the $\mathrm{V}_{\max }$ of the $1 \alpha$-hydroxylase activity. For 24-hydroxylase activity assay, tritiated 1,25(OH) ${ }_{2} \mathrm{D}_{3}$ (250 pmol, 50000 c.p.m.) from Dupont NEN (Boston, MA, USA) was used as the substrate and incubation was performed at $37^{\circ} \mathrm{C}$ for $15 \mathrm{~min}$ using $1 \mathrm{ml}$ 5\% kidney homogenate. The reactions were stopped by the addition of $1 \mathrm{ml}$ acetonitrile. Vitamin D metabolites were extracted by C18/Sep-Pak (Waters, Milford, MA, USA) and separated by high-performance liquid chromatography as described previously (Akeno et al. 1997). Activity of 24-hydroxylase is expressed in $\mathrm{fmol} / \mathrm{mg}$ protein per min.

\section{Quantitation of specific 1,25(OH ${ }_{2} \mathrm{D}_{3}$ binding}

Soluble fraction of kidney cortex was prepared as previously described (Saikatsu et al. 1993). This fraction contained total VDR in the tissue. All steps were carried out at $4{ }^{\circ} \mathrm{C}$. Briefly, mouse kidneys were homogenized $(20 \% \mathrm{w} / \mathrm{v})$ in the assay buffer containing $50 \mathrm{mM}$ Tris$\mathrm{HCl}, 500 \mathrm{mM} \mathrm{KCl}, 5 \mathrm{mM}$ dithiothreitol, $10 \mathrm{mM}$ $\mathrm{Na}_{2} \mathrm{MoO}_{4}$ and $1.5 \mathrm{mM}$ EDTA, pH 7.5 by a polytron PT10-35 tissue disrupter (Kinematica AG, Lucerne, Switzerland). The homogenates were centrifuged for $60 \mathrm{~min}$ at $300000 \mathrm{~g}$. The supernatant (cytosol) was removed and fractionated with solid $\left(\mathrm{NH}_{4}\right)_{2} \mathrm{SO}_{4}$ (enzyme grade) to $35 \%$ saturation. The soluble fraction was centrifuged for $30 \mathrm{~min}$ at 3000 r.p.m. The supernatant was discarded, and the pellets were frozen by liquid $\mathrm{N}_{2}$ and stored at $-80{ }^{\circ} \mathrm{C}$ until used for the ligand-binding study. Stock receptor (pellets) was diluted with the assay buffer (dilution 1:10), and $350 \mu \mathrm{l}$ receptor solution was incubated with various concentrations of tritiated $1,25(\mathrm{OH})_{2} \mathrm{D}_{3}$ in the presence or absence of $500 \mathrm{ng}$ unlabeled $1,25(\mathrm{OH})_{2} \mathrm{D}_{3}$ for $16 \mathrm{~h}$ at $4{ }^{\circ} \mathrm{C}$. Separation of bound from free hormone was achieved by the addition of $150 \mu$ l dextran-coated charcoal suspension. The protein in the preparations was measured. Results are expressed as fmol of $1,25(\mathrm{OH})_{2} \mathrm{D}_{3}$ receptor/mg protein.

\section{Statistical analysis}

The data are described as means \pm S.E.M. Differences between treated and untreated groups were assessed by Student's $t$-test. Multiple comparisons were evaluated by ANOVA followed by Fisher's protected least significant difference. Statistical analysis was performed with the Statview 4.02 software package (Abacus Concepts Inc., Berkeley, CA, USA). A $P$ value of $<0.05$ was considered statistically significant.

\section{Results}

Effects of dexamethasone on plasma calcium, phosphorus, and $1,25(\mathrm{OH})_{2} \mathrm{D}_{3}$

Mice were injected s.c. with dexamethasone $(2 \mathrm{mg} / \mathrm{kg}$ per day s.c.) for 5 successive days, and the plasma parameters were measured $24 \mathrm{~h}$ after the last injection of steroid. Dexamethasone significantly increased plasma calcium in both groups (NCD and LCD) (Table 1). The plasma phosphorus concentration decreased with administration of dexamethasone in NCD mice, but did not change in LCD mice. Calcium restriction by the LCD diet resulted in a significant decrease in plasma calcium and a significant increase in immunoassayable plasma PTH values. Dexamethasone markedly reduced plasma PTH concentrations coincident with an elevation in plasma calcium concentrations in the LCD group, but did not affect PTH levels in NCD mice. We also examined the effect of dexamethasone on plasma $1,25(\mathrm{OH})_{2} \mathrm{D}_{3}$ concentration. Dexamethasone did not significantly change plasma $1,25(\mathrm{OH})_{2} \mathrm{D}_{3}$ concentrations from control values in either dietary group. However, feeding the LCD diet for 2 weeks significantly increased the plasma concentrations of $1,25(\mathrm{OH})_{2} \mathrm{D}_{3}$ over those in the NCD group (Table 1).

Effects of dexamethasone on renal $1 a$-hydroxylase, 24-hydroxylase, and VDR expression in normally fed mice

Total RNA from the kidneys of NCD mice injected with dexamethasone (2 mg/kg per day s.c.) or with vehicle was subjected to Northern blot analysis using VDR, $1 \alpha-$ hydroxylase, and 24-hydroxylase cDNA probes (Fig. 1). Dexamethasone increased VDR mRNA abundance and clearly elevated the tissue content of 24-hydroxylase transcripts, while the abundance of renal $1 \alpha$-hydroxylase mRNA did not change significantly after 5 days of steroid injections. Activities of renal $1 \alpha$ - and 24-hydroxylase were compared with the abundance of these mRNAs in vehicle- and dexamethasone-treated mice (Fig. 2). Increased renal 24-hydroxylase activity with dexamethasone treatment in NCD mice was well correlated with increased mRNA abundance. In contrast, $1 \alpha$-hydroxylase activity and mRNA abundance were not changed in 
Table 1 Effects of dexamethasone (Dex) on plasma Ca, P, PTH and 1,25(OH) ${ }_{2} \mathrm{D}_{3}$ concentrations in mice. Values are means \pm S.E.M. of $5-10$ mice

\begin{tabular}{|c|c|c|c|c|}
\hline & $\begin{array}{l}\text { Ca } \\
(\mathrm{mg} / \mathrm{dl})\end{array}$ & $\begin{array}{l}\mathbf{P} \\
(\mathrm{mg} / \mathrm{dl})\end{array}$ & $\begin{array}{l}\text { PTH } \\
(\mathrm{pg} / \mathrm{ml})\end{array}$ & 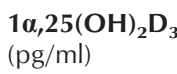 \\
\hline \multicolumn{5}{|l|}{ Treatment } \\
\hline Vehicle & $8 \cdot 6 \pm 0 \cdot 1$ & $7 \cdot 3 \pm 0 \cdot 2$ & $10 \pm 3$ & $88 \pm 8$ \\
\hline +Dex & $9 \cdot 4 \pm 0 \cdot 2^{* * *}$ & $6 \cdot 6 \pm 0 \cdot 2^{*}$ & $6 \pm 2$ & $82 \pm 9$ \\
\hline \multicolumn{5}{|l|}{ LCD } \\
\hline Vehicle & $7 \cdot 9 \pm 0 \cdot 2 \dagger \dagger$ & $6 \cdot 9 \pm 0 \cdot 3$ & $30 \pm 4+†$ & $195 \pm 25+\dagger$ \\
\hline +Dex & $9 \cdot 7 \pm 0 \cdot 2^{* * *}$ & $7 \cdot 3 \pm 0 \cdot 4$ & $7 \pm 2^{* * *}$ & $246 \pm 36$ \\
\hline
\end{tabular}

8-week-old mice were fed either an NCD or an LCD diet for 2 weeks. They were injected s.c. with dexamethasone ( $2 \mathrm{mg} / \mathrm{kg}$ per day) for 5 days. Blood was collected $24 \mathrm{~h}$ after the last injection and the parameters indicated were measured as described in Materials and Methods.

${ }^{*} P<0 \cdot 05,{ }^{* *} P<0 \cdot 001$ compared with vehicle control in each group. $+\uparrow P<0 \cdot 01$ compared with vehicle control NCD group.

NCD mice; these mice expressed only very low constitutive amounts of $1 \alpha$-hydroxylase message and protein that were not responsive to dexamethasone.

\section{Effect of dexamethasone in mice fed an LCD diet}

The presence of VDR in mouse kidneys was examined by receptor binding study. Figure 3 depicts the binding of increasing concentrations of $\left[{ }^{3} \mathrm{H}\right] 1,25(\mathrm{OH})_{2} \mathrm{D}_{3}$ in three groups of mice. Figure 3 and Table 2 show that dexamethasone did not significantly alter the number of VDR in LCD mice, and that restricting calcium and vitamin D did not influence the functional receptor expression. The affinity of VDR for $1,25(\mathrm{OH})_{2} \mathrm{D}_{3}$ was unchanged in these groups $\left(\mathrm{K}_{\mathrm{d}} 0 \cdot 10-0 \cdot 12 \mathrm{nM}\right)$. The LCD diet did not, in itself, affect VDR mRNA abundance, but dexamethasone administration modestly elevated VDR expression in mice fed the LCD diet (Fig. 4). We next assessed the effect in vivo of dexamethasone administration on renal $1 \alpha$-hydroxylase expression in mice (Fig. 5). Renal $1 \alpha-$ hydroxylase mRNA abundance and enzyme activity were markedly increased in mice fed the LCD diet compared with normal mice. Dexamethasone administration at a dose of $2 \mathrm{mg} / \mathrm{kg}$ per day led to a modest but significant fall in 1 $\alpha$-hydroxylase mRNA expression and enzyme activity. In contrast, 24-hydroxylase mRNA expression and enzyme activity increased 16- and 9-fold respectively in LCD mice (Fig. 6). In itself, restriction of calcium and vitamin $\mathrm{D}$ intake for 2 weeks in mice decreased renal 24-hydroxylase mRNA expression and enzyme activity.

\section{Effect of dexamethasone on renal 24-hydroxylase expression in} vitamin $D$ excess

We assessed the effect of $1,25(\mathrm{OH})_{2} \mathrm{D}_{3}$ excess on renal 24-hydroxylase expression. The increase in 24hydroxylase mRNA abundance and activity occurring with dexamethasone was completely abolished in mice that were also injected with $0 \cdot 24 \mathrm{nmol} / \mathrm{kg} 1,25(\mathrm{OH})_{2} \mathrm{D}_{3}$ for 5 days (Fig. 7). Although no longer responsive to dexamethasone, renal mRNA expression and enzyme activity of 24-hydroxylase were much greater in mice receiving $1,25(\mathrm{OH})_{2} \mathrm{D}_{3}$ than in those without this treatment (Fig. 7).

\section{Discussion}

Administration of glucocorticoids such as dexamethasone enhances bone resorption and decreases bone formation to induce osteopenia (Lukert \& Raisz 1990), while vitamin D metabolites, especially $1,25(\mathrm{OH})_{2} \mathrm{D}_{3}$, have important roles in maintaining bone integrity. However, the effects of glucocorticoids on vitamin D metabolism are controversial (Lukert \& Raisz 1990, Reid 1997). The present study was undertaken to define how in vivo administration of dexamethasone influences vitamin $\mathrm{D}$ metabolism through the expression of $25 \mathrm{OHD}_{3}-1 \alpha$-hydroxylase and -24-hydroxylase in the kidney.

Dexamethasone markedly elevates plasma calcium levels in mice fed a normal diet as well as in mice with dietary calcium and vitamin D restriction. The hypercalcemia induced by a pharmacologic dose of dexamethasone may reflect an overwhelming degree of bone resorption (Gronowicz et al. 1990, Conaway et al. 1996), although glucocorticoids decrease intestinal absorption of calcium (Klein et al. 1977, Aloia et al. 1984) and increase urinary calcium excretion (Suzuki et al. 1983, Reid \& Ibbertson 1987, Cosman et al. 1994). Plasma levels of $1,25(\mathrm{OH})_{2} \mathrm{D}_{3}$ are unlikely to cause the increased concentrations of plasma calcium seen in dexamethasone-treated mice, since steroid administration did not affect the plasma $1,25(\mathrm{OH})_{2} \mathrm{D}_{3}$ concentrations in normally fed or LCD mice.

Since $1,25(\mathrm{OH})_{2} \mathrm{D}_{3}$, an important regulator of calcium metabolism, is synthesized in the renal proximal tubules by 


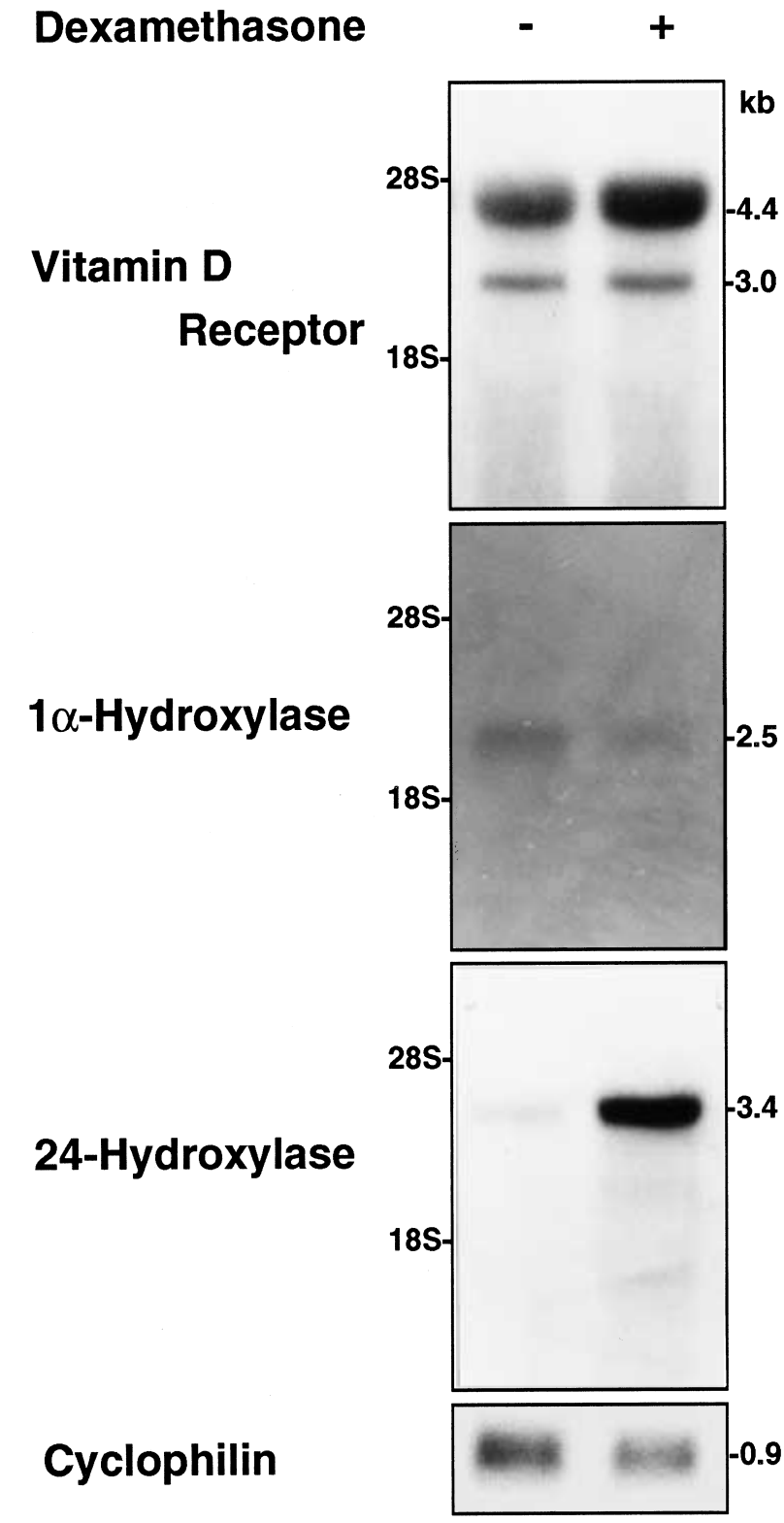

Figure 1 Northern blot analysis of total RNA from the kidneys of NCD mice. Mice were given a daily s.c. injection of either vehicle or dexamethasone $(2 \mathrm{mg} / \mathrm{kg}$ ) for 5 successive days. Total RNA ( $20 \mu \mathrm{g}$ for 24 -hydroxylase and VDR; $30 \mu \mathrm{g}$ for $1 \alpha$-hydroxylase) was extracted and subjected to Northern blot analysis. Nylon membranes were hybridized with vitamin $D$ receptor,

$1 \alpha$-hydroxylase, 24 -hydroxylase and cyclophilin cDNA probes.

the specific enzyme, 1 $\alpha$-hydroxylase (DeLuca 1988, Haussler et al. 1998), monitoring of 1 $\alpha$-hydroxylase gene expression in glucocorticoid-treated animals is of special interest. The recent cloning of a mouse $1 \alpha$-hydroxylase cDNA (Takeyama et al. 1997) enabled us to compare $1 \alpha$-hydroxylase mRNA expression with enzyme activity. In normally fed mice, $1 \alpha$-hydroxylase mRNA expression
A

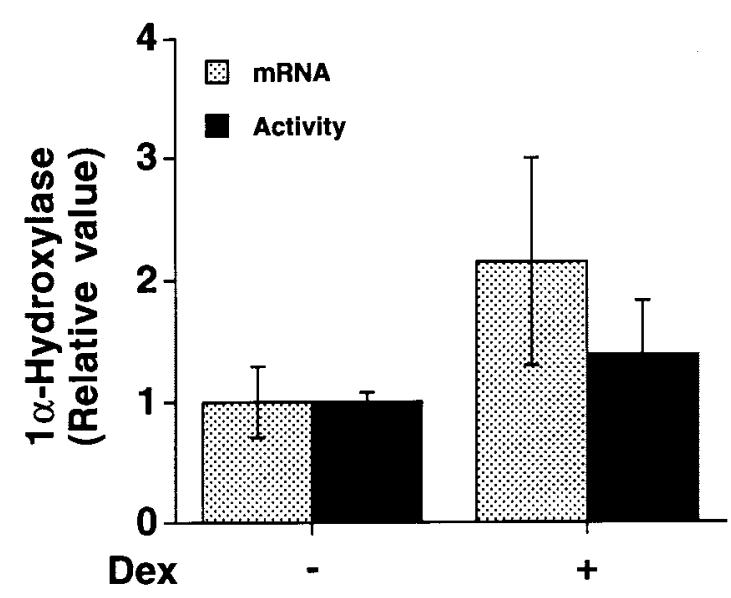

B

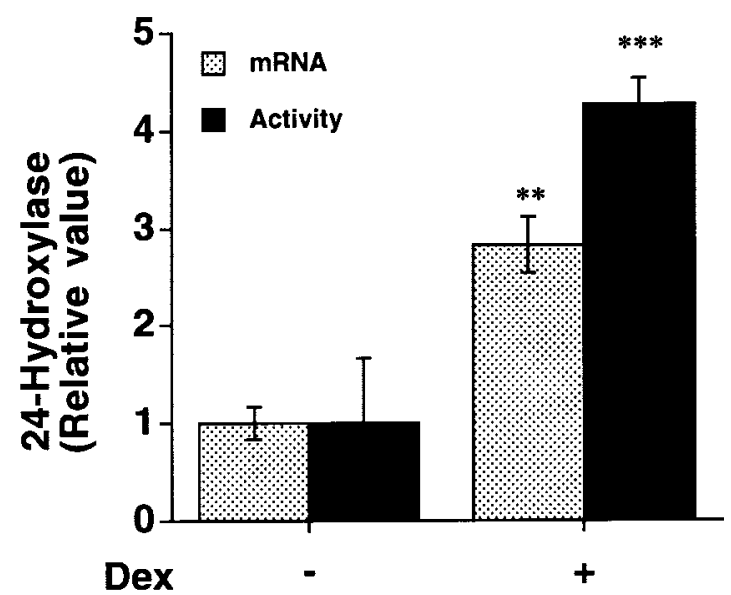

Figure 2 Effects of dexamethasone (Dex) on $1 \alpha$-hydroxylase (A) and 24-hydroxylase (B) expression in the NCD mouse kidney. Mice were injected s.c. with either vehicle or dexamethasone $(2 \mathrm{mg} / \mathrm{kg})$ for 5 days and killed $24 \mathrm{~h}$ after the last injection. The amounts of hydroxylase mRNA were determined by quantitative Northern blot analysis (dotted bars), and enzyme activity (solid bars) were measured in kidney homogenate as described in Materials and Methods. Data are means \pm S.E.M. of five mice.

and enzyme activity was not affected by a pharmacologic dose $(2 \mathrm{mg} / \mathrm{kg}$ per day) of dexamethasone, because the expression was very low. We then studied mice with restricted calcium and vitamin D intake and consequently elevated $1 \alpha$-hydroxylase expression. The present study showed that dexamethasone modestly suppressed both mRNA abundance and activity of renal $1 \alpha$-hydroxylase in such animals. Moreover, glucocorticoids influenced inducible but not basal expression of renal $1 \alpha$-hydroxylase. Although the glucocorticoid modestly increased VDR gene expression, the steroid did not significantly alter 


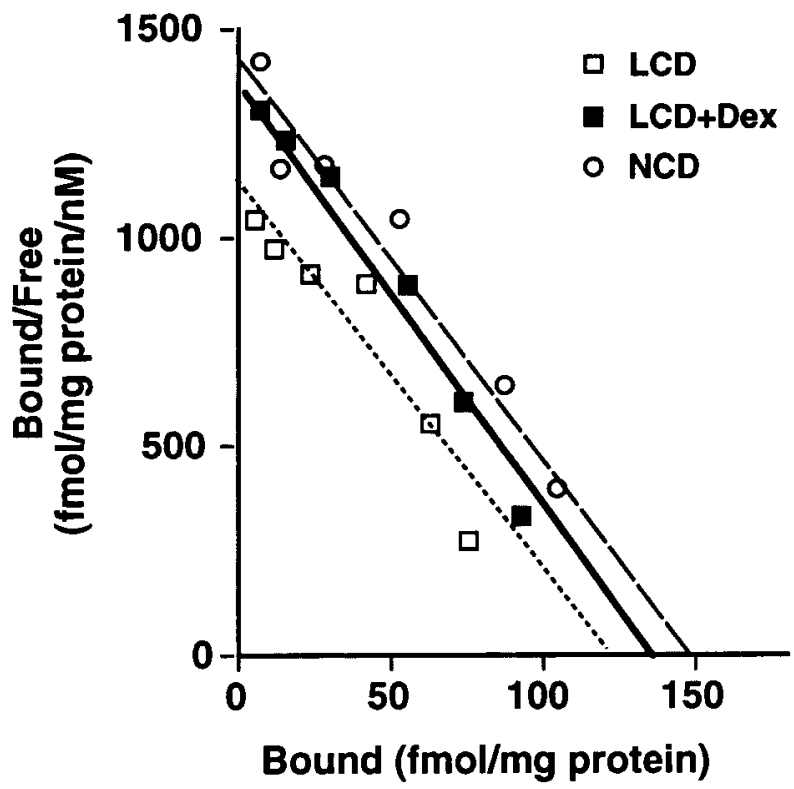

Figure 3 Scatchard plots of specific $\left[{ }^{3} \mathrm{H}\right] 1,25(\mathrm{OH})_{2} \mathrm{D}_{3}$ binding to renal VDR preparations of mice treated with vehicle or dexamethasone (Dex). Mice fed the LCD diet were injected with either vehicle (dotted line) or dexamethasone (solid line) at a dose of $2 \mathrm{mg} / \mathrm{kg}$ for 5 successive days. Results for the NCD group (dashed line) are also shown. These plots are representative of data obtained from four independent binding experiments.

functional VDR expression and $1,25(\mathrm{OH})_{2} \mathrm{D}_{3}$ concentrations in plasma. Mild inhibition of $1 \alpha$-hydroxylase gene expression by dexamethasone would not result from the alteration of activated VDR binding on a putative negatively acting vitamin D-responsive element in a $5^{\prime}$-flanking region of the gene.

In contrast, subcutaneous cortisol injections in chicks reportedly stimulated $1 \alpha$-hydroxylase activity in renal tubule preparations (Spanos et al. 1977). Further, a more

Table 2 Effect of dexamethasone (Dex) treatment on $1,25(\mathrm{OH})_{2} \mathrm{D}_{3}$ receptors in mouse kidneys. Values are means \pm S.E.M. of four mice

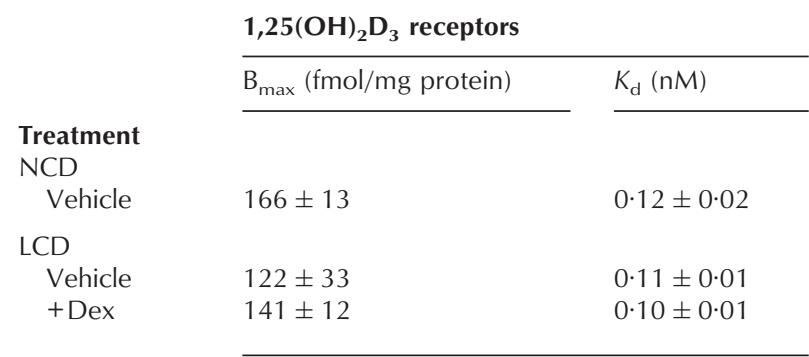

8-week-old mice were fed either an NCD or an LCD diet for 2 weeks. They were injected s.c. with dexamethasone $(2 \mathrm{mg} / \mathrm{kg}$ per day) for 5 days.

Kidneys were removed and VDR was prepared as described in Materials and Methods. $K_{\mathrm{d}}$ and $\mathrm{B}_{\max }$ were calculated from Scratchard analysis.

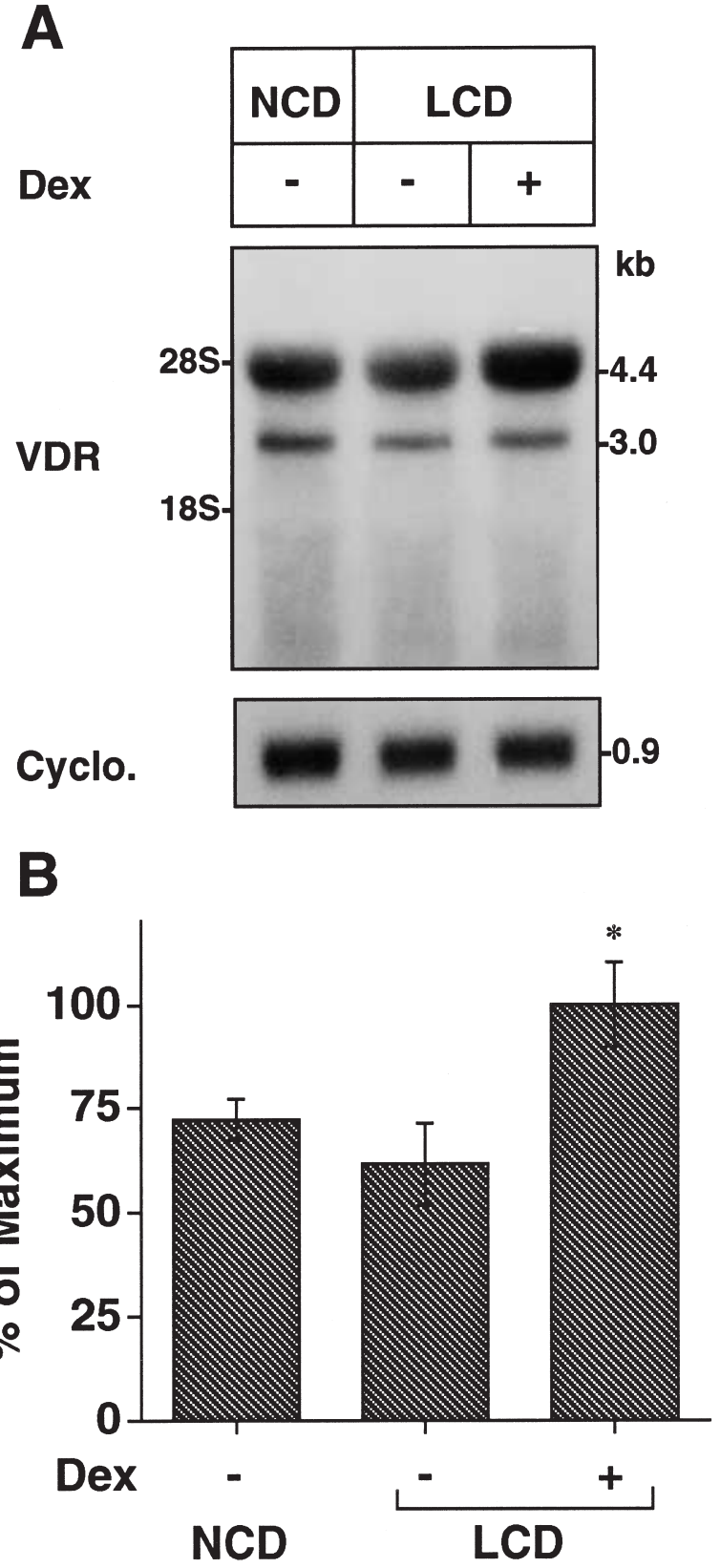

Figure 4 Northern blot analysis of VDR mRNA in kidneys of mice treated with dexamethasone (Dex). Mice fed the LCD diet were injected s.c. with either vehicle or dexamethasone $(2 \mathrm{mg} / \mathrm{kg})$ for 5 days. Results for the NCD group are also shown.

(A) Representative Northern blots of $20 \mu \mathrm{g}$ total RNA and

(B) determination of VDR mRNA abundance. VDR mRNA abundance was normalized to cyclophilin (Cyclo.) mRNA concentration. Data are means \pm S.E.M. of five mice. ${ }^{*} P<0 \cdot 05$ compared with LCD control.

recent clinical study found that pharmacologic doses of glucocorticoid used to treat patients with multiple sclerosis caused increased concentrations of plasma $1,25(\mathrm{OH})_{2} \mathrm{D}_{3}$ 
A

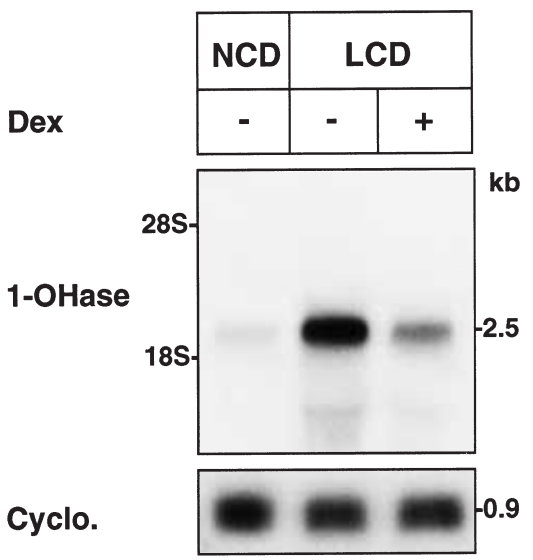

B

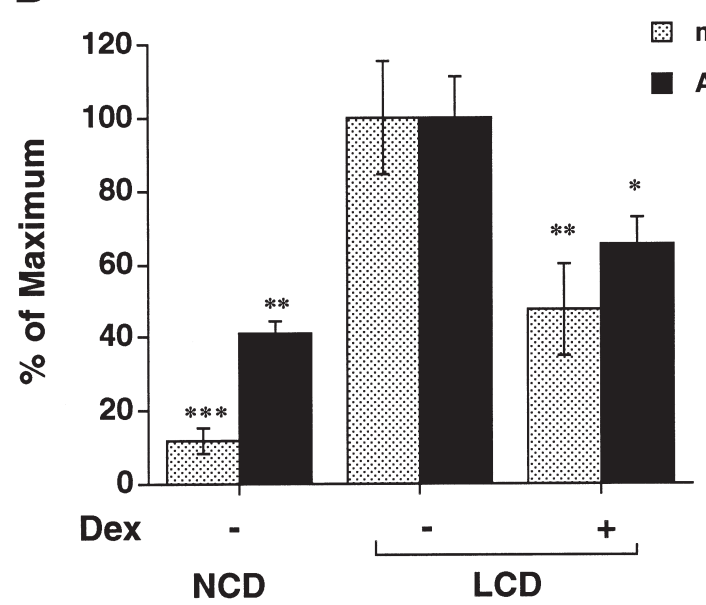

Figure 5 Effects of dexamethasone (Dex) on $1 \alpha$-hydroxylase mRNA abundance and activity in the kidneys of LCD mice. Mice fed the LCD diet were injected s.c. with either vehicle or dexamethasone $(2 \mathrm{mg} / \mathrm{kg}$ ) for 5 successive days. Results for the NCD group are also shown. (A) Northern blots of total RNA $(30 \mu \mathrm{g})$ for $1 \alpha$-hydroxylase (1-OHase) and cyclophilin (Cyclo.) mRNAs. (B) Determination of $1 \alpha$-hydroxylase mRNA abundance (dotted bars) and activity (solid bars). The $1 \alpha$-hydroxylase mRNA abundance were determined by densitometry of the Northern blots and normalized relative to that of cyclophilin mRNA. The $1 \alpha$-hydroxylase activity was measured in kidney homogenates with $25 \mathrm{OHD}_{3}$. The activities (means \pm S.E.M.) of NCD - Dex, LCD - Dex and LCD+Dex were $1 \cdot 8 \pm 0 \cdot 2,4 \cdot 5 \pm 0.5$ and $2 \cdot 9 \pm 0.35 \mathrm{fmol} / \mathrm{mg}$ protein per min respectively. Data are expressed as a percentage of the maximum (LCD - Dex mice) and are means \pm S.E.M. of five mice. ${ }^{*} P<0 \cdot 05,{ }^{* *} P<0 \cdot 01$ and ${ }^{* * *} P<0 \cdot 001$ compared with LCD - Dex.

(Cosman et al. 1994). The basis of the apparent discrepancy between these previous findings (Spanos et al. 1977, Cosman et al. 1994) and ours is unknown. We have shown that the glucocorticoid reduced renal $1 \alpha$-hydroxylase mRNA abundance and enzyme activity without marked
A

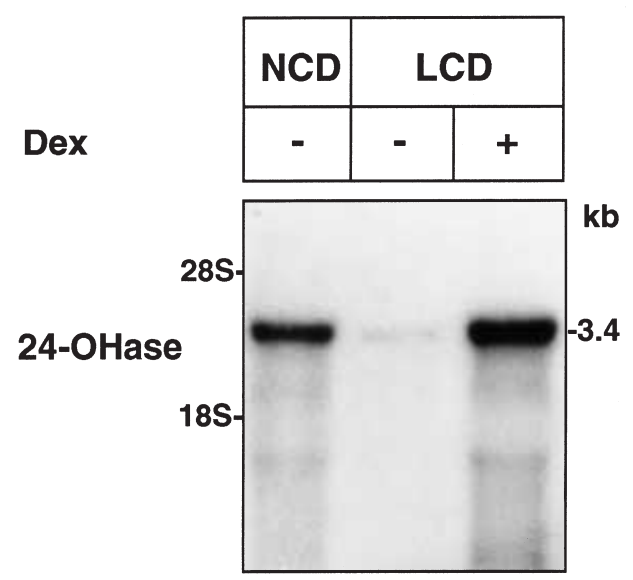

Cyclo.

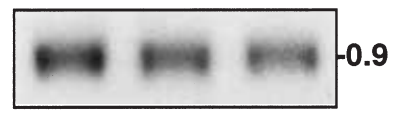

B

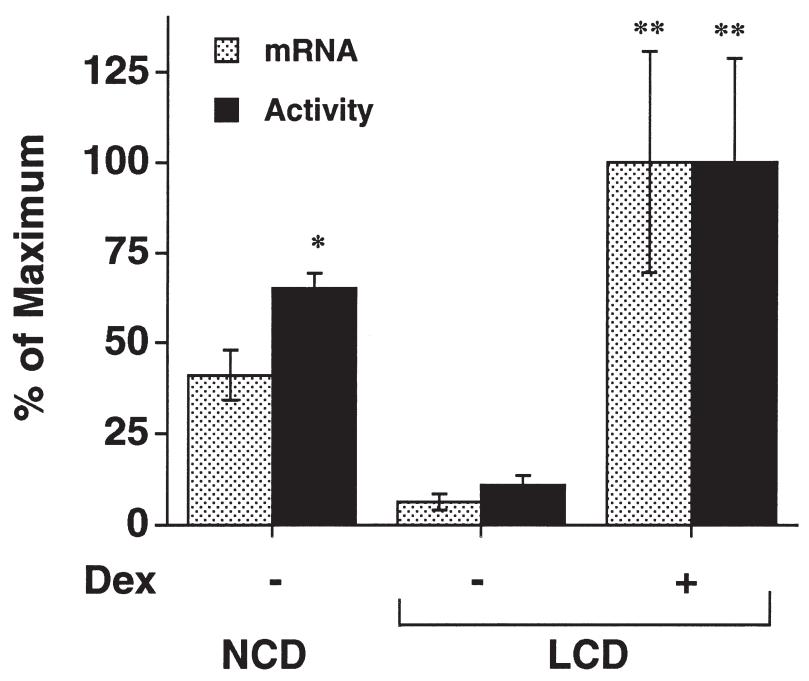

Figure 6 Effects of dexamethasone (Dex) on renal 24-hydroxylase (24-OHase) mRNA abundance and activity in LCD mice. Results for the NCD group are also shown. Dexamethasone was administered at a dose of $2 \mathrm{mg} / \mathrm{kg}$ for 5 days. (A) Northern blots of total RNA $(20 \mu \mathrm{g})$ and (B) determination of 24-hydroxylase mRNA abundance (dotted bars) and activity (solid bars). The 24-hydroxylase mRNA concentrations were measured densitometrically. Activity was measured using kidney homogenates and $\left[{ }^{3} \mathrm{H}\right]$ labeled $1,25(\mathrm{OH})_{2} \mathrm{D}_{3}$ substrate. The activities (means \pm S.E.M) of NCD - Dex, LCD - Dex and LCD+Dex were $8 \cdot 7 \pm 0 \cdot 6,1 \cdot 5 \pm 0.4$ and $13.5 \pm 3.95 \mathrm{fmol} / \mathrm{mg}$ protein per min respectively. Data are expressed as a percentage of the maximum $\left(\mathrm{LCD}+\right.$ Dex mice) and are means \pm S.E.M. of five mice. ${ }^{*} P<0 \cdot 05$ and ${ }^{* *} P<0.01$ compared with LCD - Dex. 
changes in plasma phosphate concentration, which is a potent regulator of renal $1 \alpha$-hydroxylase. This result suggests that glucocorticoids may act directly on the kidney to suppress 1 $\alpha$-hydroxylase expression. An

A

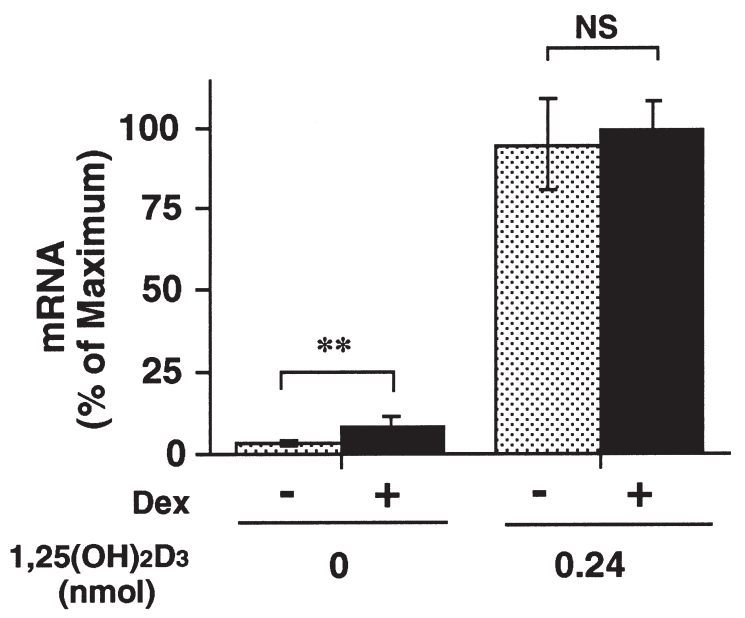

24-OHase

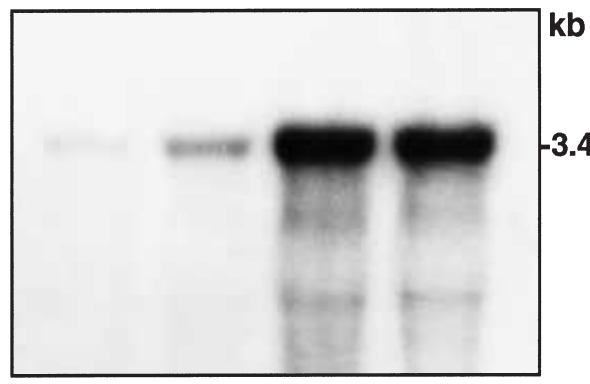

$\begin{array}{lll}\text { Cyclo. } & 0.9 \\ & \end{array}$

B

NS

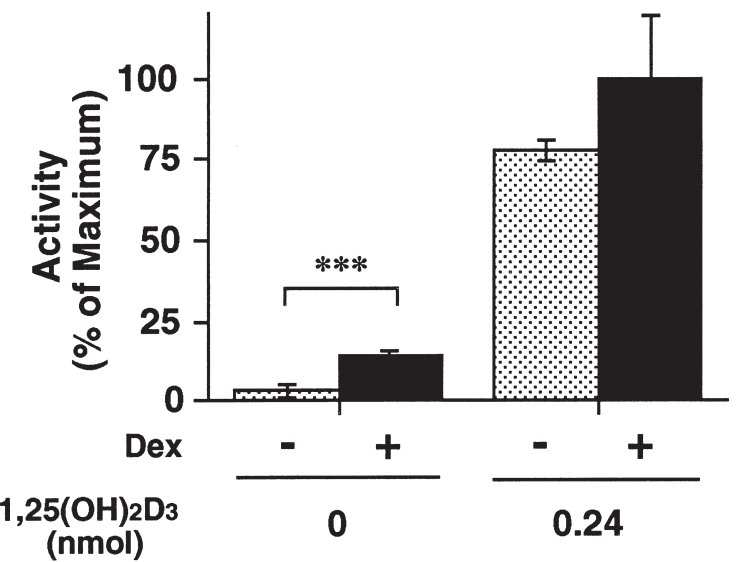

alternative explanation is that during restriction of calcium and vitamin D intake for 2 weeks mice develop hypocalcemia associated with hyperparathyroidism; these abnormalities are decreased when dexamethasone increases bone resorption. Since PTH is a principal stimulator of $1 \alpha$-hydroxylase activity (Horiuchi et al. 1977), glucocorticoid-induced suppression of renal $1 \alpha-$ hydroxylase expression in LCD mice is likely to have resulted from a decrease in plasma PTH concentration. Also, it is possible that the elevation of plasma calcium concentrations by glucocorticoid treatment suppresses the $1 \alpha$-hydroxylase expression in the kidney (Trechsel et al. 1980). In contrast, dexamethasone administration to NCD mice did not affect $1 \alpha$-hydroxylase expression. This finding is explained by the low oscillation of plasma PTH concentrations in mice treated with dexamethasone and vehicle.

Although many investigators have indicated that 24hydroxylase gene is activated by the binding of $1,25(\mathrm{OH})_{2} \mathrm{D}_{3}-\mathrm{VDR}$ complexes on the gene promoter (Ohyama et al. 1994, Zierold et al. 1994), the effect of dexamethasone on 24-hydroxylase gene expression is not known. The present studies have clearly demonstrated that dexamethasone administration caused a large increase in renal mRNA abundance and enzyme activity of 24hydroxylase. Moreover, we have demonstrated that the magnitude of the increase in enzyme expression is proportional to calcium and vitamin $\mathrm{D}$ restriction. Excess of either $1,25(\mathrm{OH})_{2} \mathrm{D}_{3}$ or dexamethasone led to marked stimulation of 24-hydroxylase expression in mouse kidney, while the administration of both together did not additively induce the enzyme, suggesting that substantial amounts of $1,25(\mathrm{OH})_{2} \mathrm{D}_{3}$ result in maximal induction of 24-hydroxylase expression in these mice. In NCD mice with moderate induction of 24-hydroxylase, dexamethasone significantly elevated the enzyme expression. This suggests that $24,25(\mathrm{OH})_{2} \mathrm{D}_{3}$ production is increased in disorders such as multiple sclerosis, which are treated with

Figure 7 Effects of dexamethasone (Dex) on $1,25(\mathrm{OH})_{2} \mathrm{D}_{3}$ induced increase in renal 24-hydroxylase mRNA abundance and enzyme activity in mice. Mice fed the NCD diet were injected s.c. with either vehicle or $1,25(\mathrm{OH})_{2} \mathrm{D}_{3}(0 \cdot 24 \mathrm{nmol} / \mathrm{kg})$ and either vehicle (dotted bars) or $2 \mathrm{mg} / \mathrm{kg}$ dexamethasone (solid bars) for 5 successive days. Animals were killed $24 \mathrm{~h}$ after the last injection. (A) Total RNA $(20 \mu \mathrm{g})$ was extracted and subjected to Northern blot analysis. 24-Hydroxylase mRNA concentration was normalized relative to that of cyclophilin mRNA. (B) Renal 24-hydroxylase activity in mice was measured as described in Fig. 6. The activities (means \pm S.E.M) of vehicle - Dex, vehicle+Dex, $+1,25(\mathrm{OH})_{2} \mathrm{D}_{3}-$ Dex and $+1,25(\mathrm{OH})_{2} \mathrm{D}_{3}+$ Dex were $43 \cdot 0 \pm 5 \cdot 0$, $78 \cdot 8 \pm 10 \cdot 6,437 \pm 18$ and $561 \pm 107 \mathrm{fmol} / \mathrm{mg}$ protein per min. Mice treated with both $0 \cdot 24 \mathrm{nmol} 1,25(\mathrm{OH})_{2} \mathrm{D}_{3}$ and $2 \mathrm{mg}$ dexamethasone had maximal activity of 24-hydroxylase which is expressed as $100 \%$. Data are means \pm S.E.M. of four mice. ${ }^{* *} P<0 \cdot 01$ and ${ }^{* *} P<0 \cdot 001$ difference between vehicle- and dexamethasonetreated groups. NS, not significantly different. 
pharmacologic doses of glucocorticoids. Alterations in vitamin $\mathrm{D}_{3}$ metabolism may contribute to the loss of bone mineral induced by the steroids.

The present study also showed that dexamethasone did not alter VDR expression in mouse kidneys. Several reasons could help to explain the increased expression of renal 24-hydroxylase seen with glucocorticoid treatment. Since dexamethasone treatment markedly elevated 24hydroxylase mRNA abundance in UMR-106 osteoblastic cells (I Kurahashi \& N Horiuchi, unpublished results), the steroid could act directly on the cells and activate 24hydroxylase gene transcription via putative glucocorticoidresponsive elements, although these elements have not been identified in the 24-hydroxylase promoter. Recent studies (Armbrecht et al. 1996, 1998) have reported the importance of vitamin D metabolism in bone, especially in UMR-106 osteoblastic cells. PTH and insulin potentiate the stimulation of 24-hydroxylase expression induced by $1,25(\mathrm{OH})_{2} \mathrm{D}_{3}$. This stimulation could reflect tissuespecific requirements for $1,25(\mathrm{OH})_{2} \mathrm{D}_{3}$ catabolism rather than increase synthesis of $24,25(\mathrm{OH})_{2} \mathrm{D}_{3}$ in bone. Akeno et al. (1997) showed that mice administered a pharmacologic dose of $1,25(\mathrm{OH})_{2} \mathrm{D}_{3}$ express relatively small amounts of the 24-hydroxylase transcripts in bone tissue, suggesting that it is not the predominant site of vitamin D catabolism in vivo. Thus, further studies will be required to define the physiologic and pharmacologic roles of the stimulation of 24-hydroxylase expression by $1,25(\mathrm{OH})_{2} \mathrm{D}_{3}$ and glucocorticoid in bone.

An increase in the metabolic clearance rate of $1,25(\mathrm{OH})_{2} \mathrm{D}_{3}$ results from elevations of renal and intestinal 24-hydroxylase in rats with vitamin $\mathrm{D}_{3}$ excess (Beckman et al. 1995). However, dexamethasone induced 24hydroxylase mRNA expression and enzyme activity in the present study without a significant associated change in serum $1,25(\mathrm{OH})_{2} \mathrm{D}_{3}$ in NCD and LCD mice. The most likely explanation for the difference is vitamin $\mathrm{D}$ status in animals. NCD and LCD mice treated with dexamethasone had relatively small amounts of 24-hydroxylase expression compared with those in animals with vitamin $\mathrm{D}_{3}$ or $1,25(\mathrm{OH})_{2} \mathrm{D}_{3}$ excess. Suppression of $1 \alpha$-hydroxylase activity by the steroids was small (only 30\% reduction) in LCD mice and was not observed in NCD mice. Therefore, it is likely that increase in 24-hydroxylase expression by dexamethasone administration does not affect the plasma accumulation of $1,25(\mathrm{OH})_{2} \mathrm{D}_{3}$ in low and normal vitamin $\mathrm{D}$ status. This finding is consonant with the results of clinical studies performed previously (Seeman et al. 1980, Prummel et al. 1991).

In summary, the present study has demonstrated that in LCD mice glucocorticoid excess markedly stimulates renal $25 \mathrm{OHD}_{3}-24$-hydroxylase expression and decreases renal $25 \mathrm{OHD}_{3}-1 \alpha$-hydroxylase expression without change in VDR number. Studies are currently in progress to define the details of the signal transduction pathway responsible for 24-hydroxylase gene activation by glucocorticoid.

\section{Acknowledgements}

We thank Mr K Saitoh (Yamasa Shoyu Co., Choshi, Japan) for the $1,25(\mathrm{OH})_{2} \mathrm{D}_{3}$ assay kit. This work was supported in part by Grants-in-Aid for Scientific Research from the Ministry of Education, Science and Culture of Japan.

\section{References}

Akeno N, Saikatsu S, Kawane T \& Horiuchi N 1997 Mouse vitamin D-24-hydroxylase: molecular cloning, tissue distribution, and transcriptional regulation by $1 \alpha, 25$ - dihydroxyvitamin $\mathrm{D}_{3}$. Endocrinology 138 2233-2240.

Aloia JF, Semla HM \& Yeh JK 1984 Discordant effects of glucocorticoids on active and passive transport of calcium in the rat duodenum. Calcified Tissue International 36 327-331.

Armbrecht HJ, Wongsurawat VJ, Hodam TL \& Wongsurawat N 1996 Insulin markedly potentiates the capacity of parathyroid hormone to increase expression of 25-hydroxyvitamin $\mathrm{D}_{3}-24$-hydroxylase in rat osteoblastic cells in the presence of 1,25-dihydroxyvitamin $\mathrm{D}_{3}$. FEBS Letters 393 77-80.

Armbrecht HJ, Hodam TL, Boltz MA, Partridge NC, Brown AJ \& Kumar VB 1998 Induction of the vitamin D 24-hydroxylase (CYP24) by 1,25-dihydroxyvitamin $\mathrm{D}_{3}$ is regulated by parathyroid hormone in UMR 106 osteoblastic cells. Endocrinology 139 3375-3381.

Beckman MJ, Johnson JA, Goff JP, Reinhardt TA, Beitz DC \& Horst RL 1995 The role of dietary calcium in the physiology of vitamin $\mathrm{D}$ toxicity: excess dietary vitamin $\mathrm{D}_{3}$ blunts parathyroid hormone induction of kidney 1-hydroxylase. Archives of Biochemistry and Biophysics 319 535-539.

Bikle DD, Halloran B, Fong L, Steinbach L \& Shellito J 1993 Elevated 1,25-dihydroxyvitamin D levels in patients with chronic obstructive pulmonary disease treated with prednisone. Journal of Clinical Endocrinology and Metabolism 76 456-461.

Carré M, Ayigbedé O, Miravet L \& Rasmussen H 1974 The effect of prednisolone upon the metabolism and action of 25-hydroxy- and 1,25-dihydroxyvitamin $\mathrm{D}_{3}$. Proceedings of the National Academy of Sciences of the USA 71 2996-3000.

Chesney RW, Mazess RB, Hamstra AJ, DeLuca HF \& O'Reagan S 1978 Reduction of serum 1,25-dihydroxyvitamin $D_{3}$ in children receiving glucocorticoids. Lancet ii 1123-1125.

Conaway HH, Grigorie D \& Lerner UH 1996 Stimulation of neonatal mouse calvarial bone resorption by the glucocorticoids hydrocortisone and dexamethasone. Journal of Bone and Mineral Research 11 1419-1429.

Cosman F, Nieves J, Herbert J, Shen V \& Lindsay R 1994 High-dose glucocorticoids in multiple sclerosis patients exert direct effects on the kidney and skeleton. Journal of Bone and Mineral Research 9 1097-1105.

Cushing H 1932 The basophil adenomas of the pituitary body and their clinical manifestations (pituitary basophilism). Bulletin of the Johns Hopkins Hospital 50 137-195.

DeLuca HF 1988 The vitamin D story: a collaborative effort of basic science and clinical medicine. FASEB Journal 2 224-236.

Gronowicz G, McCarthy MB \& Raisz LG 1990 Glucocorticoids stimulate resorption in fetal rat parietal bones in vitro. Journal of Bone and Mineral Research 5 1223-1230.

Haussler MR, Whitfield GK, Haussler CA, Hsieh J-C, Thompson PD, Selznick SH, Dominguez CE \& Jurutka PW 1998 The nuclear vitamin D receptor: biological and molecular regulatory properties revealed. Journal of Bone and Mineral Research 13 325-349.

Hirst M \& Feldman D $1982 a$ Glucocorticoid regulation of 1,25(OH) vitamin $\mathrm{D}_{3}$ receptors: divergent effects on mouse and rat intestine. Endocrinology 111 1400-1402. 
Hirst M \& Feldman D $1982 b$ Glucocorticoids down-regulate the number of 1,25-dihydroxyvitamin $\mathrm{D}_{3}$ receptors in mouse intestine. Biochemical and Biophysical Research Communications 105 1590-1596.

Horiuchi N, Suda T, Takahashi H, Shimazawa E \& Ogata E 1977 In vivo evidence for the intermediary role of $3^{\prime}, 5^{\prime}$-cyclic AMP in parathyroid hormone-induced stimulation of $1 \alpha, 25$-dihydroxyvitamin $\mathrm{D}_{3}$ synthesis in rats. Endocrinology 101 969-974.

Kamei Y, Kawada T, Fukuwatari T, Ono T, Kato S \& Sugimoto E 1995 Cloning and sequencing of the gene encoding the mouse vitamin D receptor. Gene 152 281-282.

Klein RG, Arnaud SB, Gallagher JC, DeLuca HF \& Riggs BL 1977 Intestinal calcium absorption in exogenous hypercortisonism. Journal of Clinical Investigation 60 253-259.

Levi M, Shayman JA, Abe A, Gross SK, McCluer RH, Biber J, Murer H, Lötscher M \& Cronin RE 1995 Dexamethasone modulates rat renal brush border membrane phosphate transporter mRNA and protein abundance and glycosphingolipid composition. Journal of Clinical Investigation 96 207-216.

Lobaugh B \& Drezner MK 1983 Measurement of 25-hydroxyvitamin D-1 $\alpha$-hydroxylase activities in mammalian kidney. Analytical Biochemistry 129 416-424.

Lukert BP \& Raisz LG 1990 Glucocorticoid-induced osteoporosis: pathogenesis and management. Annals of Internal Medicine 112 352-364.

Meyer RA Jr, Morgan PL \& Meyer MH 1994 Measurement of parathyroid hormone in the mouse: secondary hyperparathyroidism in the X-linked hypophosphatemic (Gyro, Gy) mouse. Endocrine 2 1127-1132.

Morris HA, Need AG, O'Loughlin PD, Horowitz M, Bridges A \& Nordin BEC 1990 Malabsorption of calcium in corticosteroidinduced osteoporosis. Calcified Tissue International 46 305-308.

Ohyama Y, Ozono K, Uchida M, Shinki T, Kato S, Suda T, Yamamoto O, Noshiro M \& Kato Y 1994 Identification of a vitamin D-responsive element in the $5^{\prime}$-flanking region of the rat 25-hydroxyvitamin $\mathrm{D}_{3}$ 24-hydroxylase gene. Journal of Biological Chemistry 269 10545-10550.

Ono T, Tanaka H, Yamate T, Nagai Y, Nakamura T \& Seino Y 1996 24R,25-Dihydroxyvitamin $\mathrm{D}_{3}$ promotes bone formation without causing excessive resorption in hypophosphatemic mice. Endocrinology 137 2633-2637.

Prummel MF, Wiersinga WM, Lips P, Sanders GTB \& Sauerwein HP 1991 The course of biochemical parameters of bone turnover during treatment with corticosteroids. Journal of Clinical Endocrinology and Metabolism 72 382-386.
Reeves PG, Rossow KL \& Lindlauf J 1993a Development and testing of the AIN-93 purified diets for rodents: results on growth, kidney calcification and bone mineralization in rats and mice. Journal of Nutrition 123 1923-1931.

Reeves PG, Nielsen FH \& Fahey GC Jr 19936 AIN-93 purified diets for laboratory rodents: final report of the American Institute of Nutrition Ad Hoc Writing Committee on the reformulation of the AIN-76A rodent diet. Journal of Nutrition 123 1939-1951.

Reid IR 1997 Glucocorticoid osteoporosis - mechanisms and management. European Journal of Endocrinology 137 209-217.

Reid IR \& Ibbertson HK 1987 Evidence for decreased tubular reabsorption of calcium in glucocorticoid-treated asthmatics. Hormone Research 27 200-204.

Saikatsu S, Akeno N \& Horiuchi N 1993 Comparison of single cartridge $(\mathrm{C} 18 / \mathrm{OH})$ and high performance liquid chromatography sample purification for the thymus radioreceptor assay of $1,25(\mathrm{OH})_{2} \mathrm{D}$. Klinisches Labor 39 737-744.

Seeman E, Kumar R, Hunder GG, Scott M, Heath H III \& Riggs BL 1980 Production, degradation, and circulating levels of 1,25dihydroxyvitamin $\mathrm{D}$ in health and in chronic glucocorticoid excess. Journal of Clinical Investigation 66 664-669.

Spanos E, Colston KW \& MacIntyre I 1977 Effect of glucocorticoids on vitamin D metabolism. FEBS Letters 75 73-76.

Suzuki Y, Ichikawa Y, Saito E \& Homma M 1983 Importance of increased urinary calcium excretion in the development of secondary hyperparathyroidism of patients under glucocorticoid therapy. Metabolism 32 151-156.

Takeyama K-I, Kitanaka S, Sato T, Kobori M, Yanagisawa J \& Kato S 1997 25-Hydroxyvitamin $\mathrm{D}_{3} 1 \alpha$-hydroxylase and vitamin D synthesis. Science 277 1827-1830.

Trechsel U, Eisman JA, Fischer JA, Bonjour J-P \& Fleisch H 1980 Calcium-dependent, parathyroid hormone-independent regulation of 1,25-dihydroxyvitamin D. American Journal of Physiology 239 E119-E124.

Zierold C, Darwish HM \& DeLuca HF 1994 Identification of a vitamin D-response element in the rat calcidiol (25-hydroxyvitamin $\mathrm{D}_{3}$ ) 24-hydroxylase gene. Proceedings of the National Academy of Sciences of the USA 91 900-902.

Received 16 March 1999

Revised manuscript received 10 August 1999 Accepted 16 September 1999 